Seminário de Pesquisa

Programa de Pós-Graduação

Design FAU USP

\title{
Protocolo metodológico para a criação, avaliação e aplicação de novos materiais a partir de experimentos empíricos com compósitos de fibra de tururi
}

\author{
Amanda Sousa Monteiro, Denise Dantas
}

\section{compósitos; tururi; experiência com materiais}

A presente pesquisa tem como tema o desenvolvimento de novos materiais compósitos e o objetivo é propor um protocolo metodológico para a criação, avaliação e aplicação de novos materiais a partir de experimentos empíricos que considerem o processo de design como elemento central de criação, utilizando os métodos DIY Materials (ROGNOLI et al., 2015) e Material

Curso

Doutorado

\section{Linha de Pesquisa}

Design: Processos e Linguagens

\section{Amanda Sousa Monteiro \\ MONTEIRO, S. Amanda. \\ Doutoranda na Universidade de São Paulo na pós-graduação em Design, bolsista do programa Novos Talentos do Instituto de Pesquisas Tecnológicas, mestre em Têxtil e Moda pela Universidade de São Paulo e designer de produtos pela Universidade do Estado do Pará. \\ e-mail: amandasousamonteiro@ usp.br \\ Lattes: http://lattes.cnpq. br/6873967172824882 \\ Orcid: https://orcid.org/0000- 0002-9965-0390}

\section{Denise Dantas}

Docente na Universidade de São Paulo na graduação e pós-graduação em Design, coordenadora do LabDesign FAUUSP e colíder do grupo de pesquisa Design em Ação. Realiza pesquisas em Human Centred Design, Inovação social, Materiais para o design.

e-mail: dedantas@usp.br

Lattes: http://lattes.cnpq. br/7636937300587505

Orcid: https://orcid.org/00000003-4419-6394
Driven Design (KARANA et al., 2015). Como questão central, pergunta-se: quais características que um protocolo metodológico pode apresentar tomando-se como base experimentos a partir de materiais compósitos, a fim de orientar o processo de desenvolvimento do material e da avaliação da percepção de usuários por experimentos empíricos entre tais materiais e os referidos usuários, segundo Rognoli et al. (2015) e Karana et al. (2015). O recorte é o material compósito de resina epóxi vinil éster, poliuretana à base de mamona e o tururi (Manicaria saccifera Gaertn.); As técnicas utilizadas foram o levantamento bibliográfico e entrevistas semiestruturadas através de workshops (GIL, 2002). A pesquisa encontra-se na etapa de estudo experimental, cujo objetivo é desenvolver os compósitos supracitados, gerando alternativas quanto à tecnologia utilizada e novas configurações visuais. Os dados são tratados segundo duas áreas: referentes as propriedades físicas dos materiais, através de metodologias da engenharia de materiais (CALLISTER, 2005); e sobre o design, com ferramentas de análise da experiência do usuário de Camera \& Karana (2018). Sobre a coleta de dados, foi preciso modificar o projeto de compósitos e adaptar as ferramentas de análise da experiência do usuário. Para tanto, está sendo desenvolvida uma versão virtual dos experimentos, que soluciona as questões pontuadas e outras levantadas em etapas anteriores da pesquisa. 


\section{Methodological protocol for the creation, evaluation, and application of new materials from empirical experiments with tururi fiber composites}

Amanda Sousa Monteiro, Denise Dantas

composites; tururi; experience with materials

The present research has focus on the development of new composite materials and aims to propose a methodological protocol for the creation, evaluation, and application of new materials, based on empirical experiments that consider the design process as a central element of creation and comprehends DIY Materials methods (ROGNOLI et al., 2015) and Material Driven Design (KARANA et al., 2015). As the central question we ask: what characteristics can a methodological protocol present, considering experiments with composite materials, in order to guide the process of material development and the evaluation of users' perceptions, including empirical experiments involving materials and users, in accordance with Rognoli et al. (2015) and Karana et al. (2015). As delimitations we selected composite materials of epoxy vinyl ester resin, mamonabased polyurethane, and tururi (Manicaria saccifera Gaertn.);

The applied techniques include bibliographic survey and semistructured interviews during workshops (GIL, 2002). Currently the research is in the experimental study phase, whose objective is to develop the aforementioned composites, generating alternatives regarding the technology used and new visual configurations. Data is being analyzed considering two aspects: related to the physical properties of the materials and considering methodologies of materials engineering (CALLISTER, 2005); and one related to design, considering the user experience analysis tools proposed by Camera \& Karana (2018). Regarding data collection, it was necessary to modify the design of composites and to adapt the user experience analysis tools. Thus, a virtual version of the experiments is being developed, which solves the previously mentioned problems and other questions that emerged during previous stages of the research.

\section{Referências | References}

CALLISTER, W. 2005. Fundamentals of Material Science and Engineering: An Integrated Approach. New York: John Wiley \& Sons.

CAMERA, S. \& KARANA, E. 2018. Experiential Characterization of Materials: toward a toolkit. In: Design Research Society: 1685-1705. Limerick: Catalyst. GIL, A. 2008. Como elaborar projetos de pesquisa. São Paulo: Atlas. KARANA, E.; BARATI, B.; ROGNOLI, V. \& VA-DER-LAAN, A. 2015. Material Driven Design (MDD): A Method to Design for Material Experiences. International Journal of Design 9(2): 35-54.

ROGNOLI, V.; BIANCHINIA, M.; MAFFEIA, S. \& KARANA, E. 2015. DIY Materials. Materials and Design 86(5): 692-702.

e-mail: dedantas@usp.br

Lattes: http://lattes.cnpq. br/7636937300587505

Orcid: https://orcid.org/0000-

0003-4419-6394 